This is a pre-proof copy before final changes. Final version is available online or ask author - greg.mannion@stir.ac.uk Some copies available free from publisher or via author. https://doi.org/10.1080/13504622.2018.1536926

\title{
Re-Assembling environmental and sustainability education:
}

\section{orientations from new materialism}

\author{
Dr Greg Mannion, \\ Faculty of Social Sciences (Education), \\ University of Stirling, \\ Scotland. \\ Contact: greg.mannion@stir.ac.uk \\ Orchid: 0000-0003-2233-9278 \\ Twitter:@Greg_Mannion
}

\section{Citation:}

Mannion, G. (2019). Re-assembling environmental and sustainability education: orientations from new materialism. Environmental Education Research/ Available online https://doi.org/10.1080/13504622.2018.1536926

\section{Abstract}

A growing number of scholars call for the use of New Materialist frameworks for research across social and natural sciences. In general, however, there is little rigorous, in-depth or detailed advice on how postqualitative research is to be empirically conducted. Also, what the implications might be for environmental and sustainability education remain unclear. In response, drawing on data from a place-responsive heritage education project, employing theory from Deleuze and Guattari, I provide orientations for Assemblage Pedagogy and Assemblage Research. Assemblage Pedagogy involves educating for more sustainable ways of life through: (1) Interrupting existing education assemblages and experimenting with new approaches, (2) Practicing, relating, and entangling 'from the middle', involving the human and more-than-human to actualize the capacities and relations needed, and, (3) Evoking and performing new practices and expressions designed to create more sustainable ways of life. Wider implications for researching environmental and sustainability education are considered.

Key Words: Relational, new materialism, Deleuze, environmental education, placeresponsive, assemblage. 


\section{Introduction}

Within ontological, relational, animal, and material turns (Castree 2004, Coole and Frost 2010), 'New Materialist' research is emerging across the social sciences (Deleuze 1994, Deleuze and Guattari 1987, Pickering 2005, Haraway 2003, 2008, Barad 2003, 2007; Latour 2005, Braidotti 2013). The application of New Materialism to pedagogy and educational research has also gained traction (Alaimo and Heckman 2008, Masny 2013, Lather and St. Pierre 2013, St. Pierre 2013, 2016; Snaza and Weaver 2015). These perspectives are diverse but often draw on Deleuze (1994) and Deleuze and Guattari (1987) and theories of assemblage. This article picks up these debates and extends them through applying them to environmental and sustainability education ('ESE' hereafter) and considering the associated challenges and benefits.

An assemblage is not just a collection or compilation of things. A DeleuzoGuattarian assemblage must be a collection of material, human and non-human parts with expressive capacities to affect and be affected by each other, and by other assemblages (Deleuze and Guattari 1977). The parts of an assemblage and the assemblages themselves are produced through their relations or their connectivity. These arrays of entities are decomposable and are not seamless - this means they can be put together and taken apart. Assemblages can comprise "corporeal, technological, mechanical, virtual, discursive, and imaginary" elements that are in interaction (Renold and Ivinson 2014). Deleuze and Parnet's (1977) definition draws attention to how various things come together - how they are composed (rather than merely randomly compiled). Indeed, assemblages work the way they do despite and because of their differences. Like musical notes on a composer's score, rather than being haphazardly 
scattered, it is the particular arrangement of the notes, their durations, and other mark-ups that bring about expressive affect in a listener when played in a performance by a sympathetic musician.

[An assemblage] is a multiplicity which is made up of many heterogeneous terms and which establishes liaisons, relations between them across ages, sexes and reigns different natures. Thus, the assemblage's only unity is that of co-functioning: it is a symbiosis, a 'sympathy'. (Deleuze and Parnet 1977, 52)

Across the social sciences, Buchanan (2015a) suggests that there has been something of a failure to be clear about the implications of assemblage theory. In part, Buchanan shows why it has been difficult to be true to the ideas of Deleuze and Guattari; the contemporary view also suggests not overly specifying research practices (St. Pierre 2013). Another problem comes from how meanings are perhaps getting lost in translation as terms, such as 'agéncement' are translated from French. Unlike the noun 'assemblage', the verb, agéncement, perhaps better captures the process of coming together with openness and sensitivity to what is different and what might become. Hence, there is a need to find a viable way to apply Deleuze and Guattari's ideas adequately to ESE practice and research and explore their benefits.

Using an assemblage approach can help us make post-humanism viable in pedagogy and research but why should we do this? This is an important contribution since humanistic approaches to education in general appear to have failed us to date in many ways to adequately address issues such as climate change and wider global precarity. More widely, arguments against humanism are becoming more ubiquitous and compelling. Arguments include (see Malone et al 2017) the need for a de-centreing of the human in our ontologies 
and epistemologies (for example, in solely looking to the needs of humans in definitions of sustainability or in child-centred approaches), a countering of human exceptionalism in general towards a relational orientation (in terms of, for example, human-plant, humananimal, human-place), a revision of 'stewardship' views of the environment (with its paternalistic associations of sympathy, mastery and control), a greater acceptance of environmental crisis of the Anthropocene (particularly climate change, but in connected ways food insecurity, migration, and so on), and a foregrounding of the importance of alternative ways of knowing (via, for example, indigenous knowledge, and the embodied, affective and ethical dimensions of experience). On these grounds, it is timely in ESE to begin now to explore and apply various forms of post-humanist and new materialist theory in rigorous but creative ways.

\section{New Materialist ESE}

Assemblage theory, like other New Materialist perspectives, share a desire to work in postparadigmatic ways to challenge linguistic and social constructivist approaches and require a rethinking of how materials and discourses relate (Gough 2016). New materialists argue that since people, places and materials are entangled and emergent, a relational approach is required. Another feature is how approaches decentre the human and to take a more distributed view of agency. A third is a desire to unpack the binaries seen as undergirding Western thought around themes such as nature and culture, human and non-human, idealism and materialism. With these themes in mind, New Materialism should be attractive to and have consequences for environmental and sustainability programmes and their underpinning ontologies. However, with some exceptions (see below), these efforts remain underrepresented, less securely founded, and only latterly critiqued in ESE (see Gough, 2016, Buchanan 2015, 2016). 
Some progress in New Materialist ESE is apparent when it comes to describing learner experience. Fawcett (2002) is credited with an early call for collective learning 'with' other species. Taylor (2017), drawing on Deleuze and Haraway, explicitly seek to account for more-than-human agency. Others emphasise the significance of the turn to flatter ontologies for learning within the age of the Anthropocene (Taylor and Pacini-Ketchabaw 2015). Early childhood researchers have challenged the binary of culture/nature and the idea of human stewardship of nature (Pacini-Ketchabaw and Taylor, 2015, Malone et al. 2017) where the significance of learner embodiment is common (Hackett and Somerville 2017). Lloro-Bidart (2016) asks us to consider non-human actions and human lived experiences in a relational way suggesting that other species and the human can be a community of knowers. Assemblage researchers seek to align epistemology, ontology and methodology within a linked approach to reality, representation and subjectivity (see St. Pierre 2016). However, there is a noticeable reticence in this literature to do more than describe life in new ways. Less common, is the provision of advice for educators or exemplification for researchers.

In other assemblage-oriented ESE research, there are some directions for travel (inter alia, Clarke and McPhie 2016, Ross and Mannion 2012, Mannion and Gilbert 2015, Van Poeck and Lysgaard 2016). Mannion, Fenwick and Lynch (2013) analysed teachers' experiences to argue for place-responsive pedagogy requiring planning for reciprocity between humans and the learning setting. Clarke and McPhie (2016) suggest all education regardless of whether indoors or out should move to become more place-responsive. 'Assemblage Pedagogy', in this article, can be understood as a development of an expression of place-responsive pedagogy and research (Mannion, Fenwick and Lynch 2013). Often outside of ESE, a small but increasing number of authors in different sub-fields employ Deleuzo-Guattarian ideas 
around assemblage (Leander and Rowe 2006, Hultman and Lenz Taguchi 2010, Lenz Taguchi, 2013, Rautio 2013a, 2013b, Taylor and Pacini-Ketchabaw 2015, Green and Duhn 2015, Fox and Alldred 2015, 2017). Smith and Dunkley (2017) employ assemblage theory to usefully describe child-nature relations in a study of children's roaming in outdoor settings using GPS systems.

Notably, this journal's special issue and a previous one (see the editorial from Duhn, Malone, and Tesar 2017) seek to continue to 'trouble' (inter alia) the categories of child / nature / urban, the nostalgic view of children's upbringing via nature experience, and the anthropocentrism of the idea of stewardship. Across these sources, it is commonly argued that a post-human reading of ESE requires us to stay with this trouble. To boot, it appears to require serious shifts in thinking and action. The result, inadvertently perhaps, is a positioning of post-human transformative pedagogies a bit beyond the grasp of the ordinary teacher or researcher:

Changing the entrenched habits of modern western humanist thought, which are so adept at dividing humans off from nature, requires persistence, vigilance and a preparedness to take risks. It is hard work. It requires us to continually interrogate what it means to be human, to resituate humans firmly within the environment, and to resituate the environment within the ethical domain. (Taylor 2017, 3)

\section{Assemblage theory as toolbox}

We can expect that any good research will not usually exactly follow a pre-given formula for data collection, analysis and write-up and New Materialist approaches are not different in that respect. In order to deploy Deleuze and Guattari's ideas in research, we are required to 
rework contemporary ontological models of what counts as methods, data, and their analysis. Yet, if valid, an ontology that asks us to link discursive and material experience will surely marry with our sensate experiences of living in the world and make some aspects of researching in this way more viable. Indeed, over a number of projects, once the shift is made to accept and work within a new onto-epistemological frame, it does seem possible to deploy Deleuze and Guattari's ideas in different ways. There are also now many good sources for support albeit often located outside of ESE literatures. There is also the attractive advantage with this way of working of having scope to create and use new concepts which could be of value to a reinvigorated ESE. Assemblage theory in ESE can be seen as a useful way forward:

A theory is exactly like a box of tools. It has nothing to do with the signifier. It must be useful. It must function. And not for itself. If no one uses it $[\ldots]$ the theory is worthless. [...] It is an instrument for multiplication and it also multiplies itself. (Deleuze speaking in conversation with Foucault. [Foucault 1977, 208]).

Perhaps core to the use Deleuze and Guatarri's philosophy, is a need to focus on pragmatic use of theory alongside questions of immanence (what can ESE do and what can learners-inplace become), rather than questions of identity (for example, what is sustainability?). In that spirit, I offer some (but not comprehensive) tool-like orientations and implications of ‘Assemblage Pedagogy’ and ‘Assemblage Research’ within ESE.

The goal of this article is both to describe and show how programming in ESE can be understood via assemblage theory. A key move is to understand how an ontology of becoming shapes the business of data collection, their analysis, and onward presentation in a research paper such as this. In showing how this works in research processes, the reader is 
invited to generate their own significance of these learners' lived experience in an outdoor environmental education programme. This empirical evidence is assembled here for its effects - the extent to which both photographs and transcribed evidence help us see or palpate how data collection and analysis occurred whilst still setting them to work now for readers. Assemblage researchers set out to produce effects, something new. Here, I set out to provide an expressive and productive account - to evoke young people's lived experiences as enfolded with, in and of a place. After Springgay and Truman (2017, 4), assemblage-oriented research, and in an important related way, assemblage pedagogies, will have an immanent quality commencing in the speculative middle "where things grow, expand and pick up speed" [...] "You have to be 'in it', situated and responsive. You are not there to report on what you find or what you seek, but to activate thought". This call for attention to unpredictable immanence applies to assemblage pedagogues, assemblage researchers and readers of their outputs alike (see Jackson 2010).

Firstly, I describe the origin and purposes of the project, Stories in the Land and our approach to assemblage curriculum making. Thereafter, we describe the approach taken to data collection before offering three general orientations for Assemblage Pedagogy. Lastly, I draw out some exemplifications and consequences for ESE.

\section{The project - Stories in the Land}

The data used in the article come from a project entitled Stories in the Land (http://storiesintheland.blogspot.co.uk) which was led by Dr Joyce Gilbert who then worked for the Royal Scottish Geographical Society. I was the funded adviser and researcher over a 
three-year period. In this work, we took 'droving' as a key eco-social practice with which schools and youth groups could engage. (See also Gilbert and Mannion 2014).

The project can be conceived as a place-responsive, arts-based, outdoor environmental education programme that connected participants from different generations from schools, youth groups and their communities with local places through journeys on the widespread network of 'drove roads' across Scotland. A 'drove road' is a route that was used - mostly in the last century - to bring livestock from one place to a market town or to bring cattle up into the higher ground to avail of summer pastures. A.R.B. Haldane (1900 - 1982), a social historian and writer, became interested in drove roads and the history of droving. His book, The Drove Roads of Scotland (1952) included a linen map showing an extensive arterial network of routes linking communities from the highlands to the lowlands (figure 1).
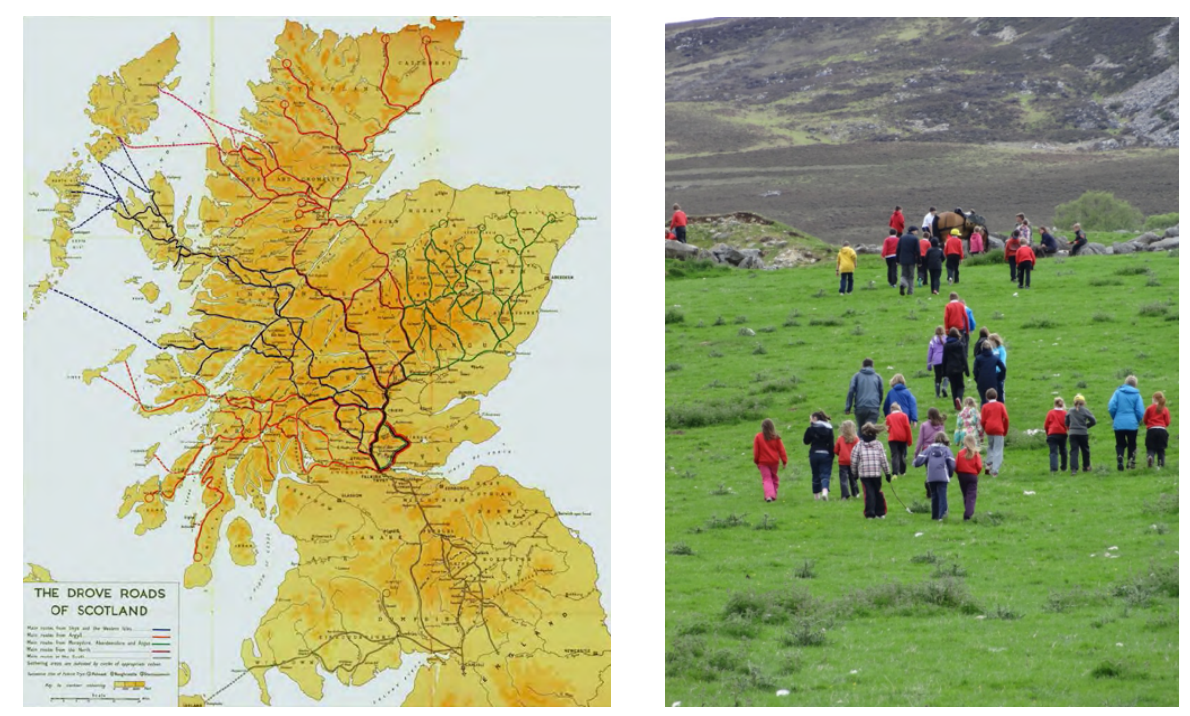

Figure $1 \& 2$. Figure 1 shows Haldane's map of the main drove routes whereupon the seasonal flow of thousands of cattle made their way from highland and coastal regions to market towns and on to England (reproduced by kind permission of Birlinn Publishers, Edinburgh). Figure 2. A school community on a community drove walk. 
At the outset, Haldane's map offered a perspective of some of the entanglements we considered potentially significant. Through taking an assemblage approach to pedagogy, we looked for actual and virtual entry points into this rhizome of roads, related practices and folklore, stories, and songs (Deleuze and Guattari 1987). The pedagogical approach of journeying on these routes and investigating practice was, for us, reminiscent of Honeyford and Watt's (2017) notion of pedagogical burrowing or the need to 'plug into' (Jackson and Mazzei 2012) rhizomes in affective ways.

Nearly every community in Scotland has a local drove route but, despite their once vital importance to Scotland's culture and economy, droving remains a largely forgotten way of life in Scotland. The Stories in the Land approach was not only a form of local history pedagogy. Our approach asked participants to respond to past generations and the places inhabited by them and to consider the use of contemporary places inhabited by us now. Starting with the local lived experience (Duhn 2012a, 2012b), and drawing on traditional oral knowledge and practice, we invited learners to affect and become affected by these practices. We saw the potential for a situated, interdisciplinary, and intergenerational form of placeresponsive pedagogy (Mannion, Fenwick and Lynch 2013). The project pedagogy was initially based on two principles arising from our reading of Deleuze and Guattari (see Mannion and Gilbert 2015): (1) people and places are reciprocally enmeshed and coemergent, and (2) people learn through making embodied responses to differences. We asked: How might our ways of life be prompted to be more sustainable in the light of the drover experience?

\section{Assemblage Curriculum}


The key idea of 'assemblage', (Deleuze and Guattari 1987, Deleuze 1994) captures the ethos of our curriculum design work. We took from Lorimer (2005) a sense of the importance of the 'more-than-human' - for example, the place elements that mattered included cattle but also local plants and their uses by drovers. We also sought to provide lived experiences of drover life that would be sensory, embodied and affective for learners. In effect, we sought to devise 'more-than-human' pedagogies which would evoke and provide opportunities for catalytic witnessing of the significance of landscape, story, material practices and the movements of animals and people in past times with a view to informing new ways of life today. We sought to maximise affective intensity for learning with, through, and in relation. Mulcahy (2012) captures the core business of the assemblage pedagogue as working to create significant 'conditions' for learners to engage and respond through making affective connections with others - human and more-than-human others. 'Good' teaching is in contact with the moving dimensions of experience that allow for affective connection. 'Basically the "good" is affectively defined as what brings maximum potential and connection to the situation" (Mulcahy, 2012, p 23).

Our assemblage approach included an oral storytelling element. Learners were to 'become collectors, creators and tellers of old and new stories inspired by these epic journeys' (project documents). Following Somerville et al (2009), we addressed our relationship with place via re-storying across certain contact zones which were for this project (inter alia) Now-The Past, School-Community, Adult-Child, Farming-Wild Space, Nature-Culture. While traditionally, these relationships are policed or in Deleuzian terms, 'territorialized' along certain relations, our desire was to de-territorialize some of these relations through reconnecting communities with their schools, learners with their pasts, and indoor learning with outdoor settings in new ways. 

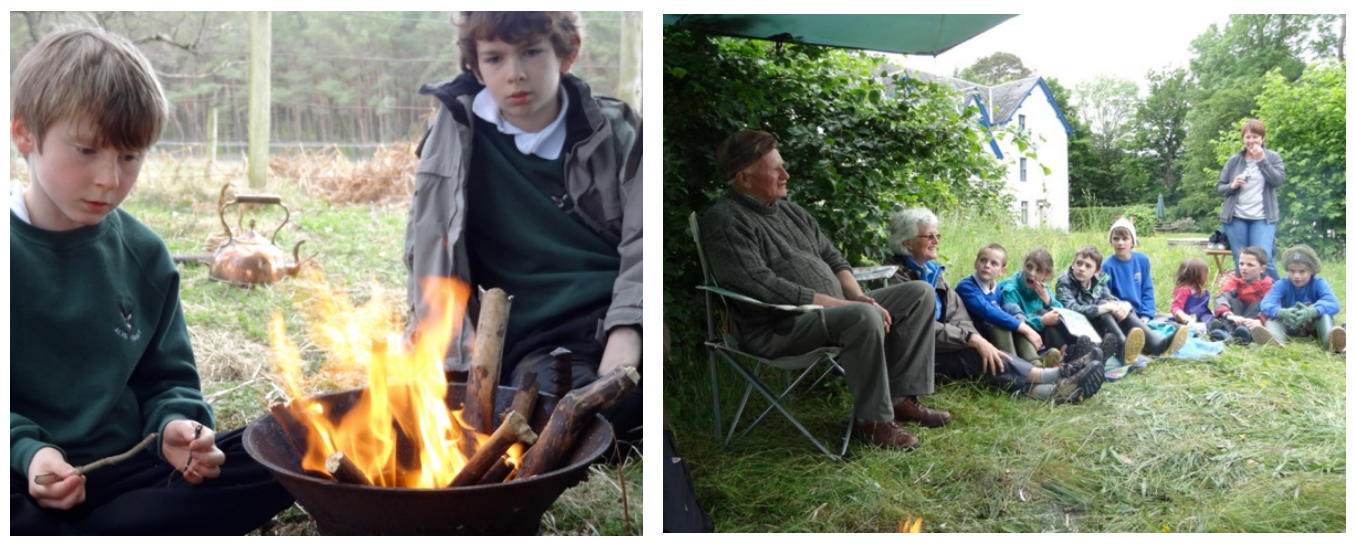

Figures $3 \& 4$. As part of the project, normal school practices of teacher delivered lessons in classrooms are de- and re-territorialized as pupils were encouraged to walk on old drove routes and were assisted in setting up impromptu drovers' camps often in sites of droving historical significance. They also met local crofter, Ronnie Campbell, who took part in the last drove in 1949 as a boy who told them stories of his past experience (Figure 4).

As well as hearing about past experiences, learners valued the opportunity to engage in practices that were affectively impactful.

Primary Pupil: You actually get to experience things. [...] And you feel it. [...] Rather than just watching it happen, you can actually do it.

The kind of curriculum making took 'droving' as a significant practice-based process where the person, animals and environment are in movement-based relation and are co-emergent (Ross and Mannion 2012). In this project, learners were invited to become similarly attuned to the environment through the practices of droving (see figures $5 \& 6$ ). Some activities allowed for intense memorable and sensory experiences. 

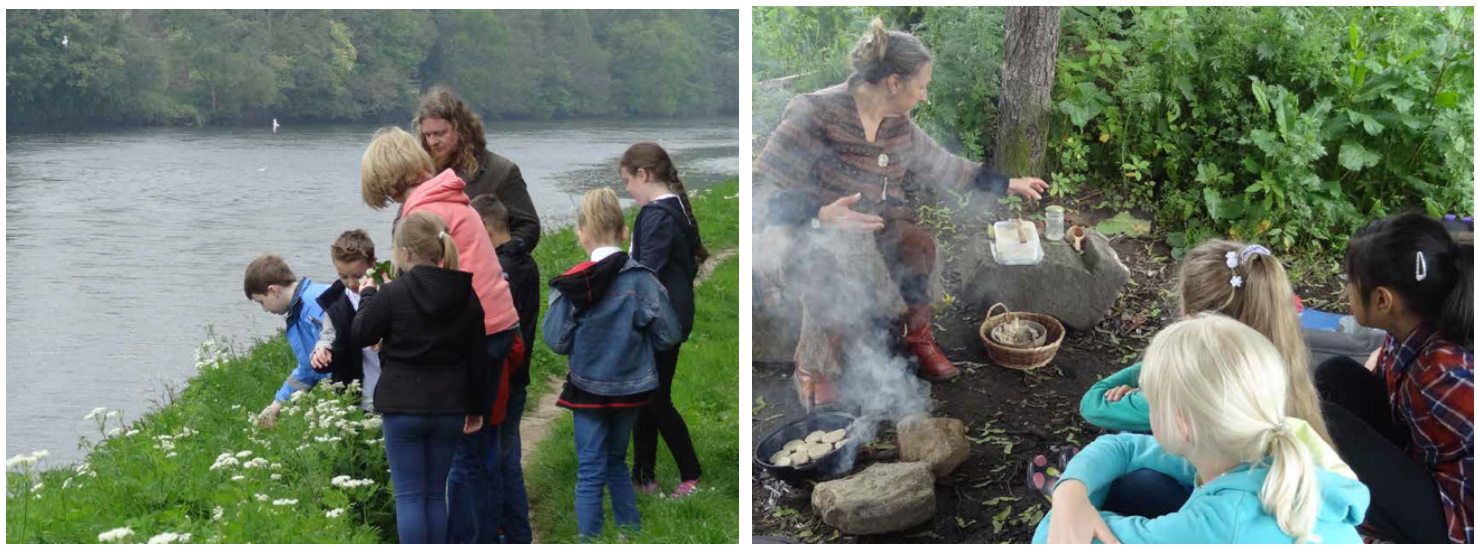

Figures $5 \& 6$. Attunement to a place comes through action in that place. On route, learners were engaged in learning through practices that were made possible by the way place-based elements came together or were brought into relation. For example, they learned about plant identification, collection and their uses in cooking using traditional recipes.

Teenage girl: And we learnt like all about like the things that we ate. And even, like we made butter and oatcakes and all that kind of thing. [...]

Our curriculum as assemblage approach countered transmission and constructivist views of learning. We followed Ingold's view that learners "do not superimpose meaning on a world ('nature' or 'physical reality') that pre-exists apart from ourselves, for to live we must dwell in the world, and to dwell we must already relate to its constituents. Meaning inheres in these relationships" (Ingold,1993, 222). Ingold's eco-social take on learning is profoundly Deleuzian: the social and the natural are together coming into being in an on-going way. Within an anthropological frame, the less cultured novice as an emergent 'point of growth' (Ingold 2003, 304) apprehends by accompanying more experienced people into practice assemblages. Learners "attend to the movements of others" to become more skilled (Ingold 2000). By his view, organisms that grow and develop can exercise agency but only in an entangled way within environments embodying skills in ways that are connected to perception and experience in that environment. Action, in contrast to mentally considered agency, includes the flow-like interplay of many diverse kinds of entities and forces in 
relation (weather, gravity, human and non-human agency). Acting in the world is experienced through undergoing the effects of the world's processes, one's own and others' actions (Ingold, 2015). Dealing with unforeseen problems was part of undergoing droving as an educational experience:

Teenage girl: Well I think I would say [...] the best way [to learn] is to go out there and do it and not talk about it and explain like in theory what could go wrong. But go out and experience what could go wrong and learn how to overcome it.

Ingold (2012) reminds us that whenever we encounter material things in a place (whether it be cattle, fire, water, or food), it is in flux with the consequence that "this matter-flow can only be followed" (Deleuze and Guattari 1987, 451) as they move, grow, decay, and get transported. Taking account of how this was for the drovers makes more apparent how it is different for us now:

Teenage girl: We had a lot more luxuries than the drovers would have had. So, it kind of gives you [a] perspective on how difficult it would have been for them.

We found out how people used plants in their day to day lives

We found out about life long ago

We found out how people managed with what they had round about them (they couldn't go to shops to buy things)

Respondent aged 12 (Questionnaire. Open Question)

\section{Assemblage Research}


My own role in this project was as a contracted researcher. Research data collection included extensive participant observation fieldwork (across days spent planning, community walking, reflection and dissemination), sound recordings of stories told, researcher and respondenttaken photographs, and over 30 transcribed focus group and other interviews with participants over a two-year period. Focus group interview data drawn upon here are summarised in Table 1. Each interview mostly had 3-7 respondents and lasted 15-60 minutes each. Participating interviewees (and their facilitators, teachers and parents [if under 16 years of age]) provided on-going written and oral informed consent for sound recording and photography (for onward use as included in this publication).

\begin{tabular}{|l|c|}
\hline Focus Group Interview Data Drawn Upon & No. of Focus Groups \\
\hline Primary school pupils: 7-12 yrs of age & 7 \\
\hline Secondary School age pupils: 13-17 yrs of age & 7 \\
\hline Teachers: 7+ schools, primary and secondary schools & 5 \\
\hline Facilitators and Assisting Adults & 12 \\
\hline & $\mathbf{3 1}$ \\
\hline
\end{tabular}

Table 1.

After Deleuze, a research-assemblage (Fox and Alldred 2015) seeks to bring into affective relation composable and decomposable human and non-human entities. For Fox and Alldred (2014), a research-assemblage should be defined in terms of the affective relations among the 'events' to be researched, the research tools and sources, the 'data' generated, and the researcher. (They also remind us that the physical spaces where research takes place, research culture, cultures, ethics committees; research outputs, editors, reviewers and readers are also part of this relational set). Within this immanent ontological frame, data are to be collected and analysed whilst being in the midst of these entities. Research assemblages are 
interventionist experiments orchestrated for producing data through the fieldwork and methods employed. The approach to researching the project also involved various different kinds of components - humans, events, technologies, frameworks, and theories. All of these together can be considered as a research assemblage (Fox and Alldred 2015).

Fox and Alldred (2017) suggest data collection involves identifying assemblages in the ecosocial world, exploring how elements affect and are affected, and identifying particular and more aggregate flows that are generated by these assemblages. In that vein, working as a participant observer, I took part in witnessing camping practices, journeyed as a member of the story tribe (see figure 8), and captured data on the hoof as events unfolded as well as in project dissemination events (figure 10). Whilst participating in project events and during interviews and field note writing, assemblage researchers attempt to apprehend points of growth as significant for the respondents involved. Hence, lived experience contains actual and virtual or immanent events with affective, sensory and embodied dimensions. Data analysis takes the onward immanent effects of an assemblage as primary; assemblages produce rather than, in hindsight, attempt to mirror or objectively represent reality.
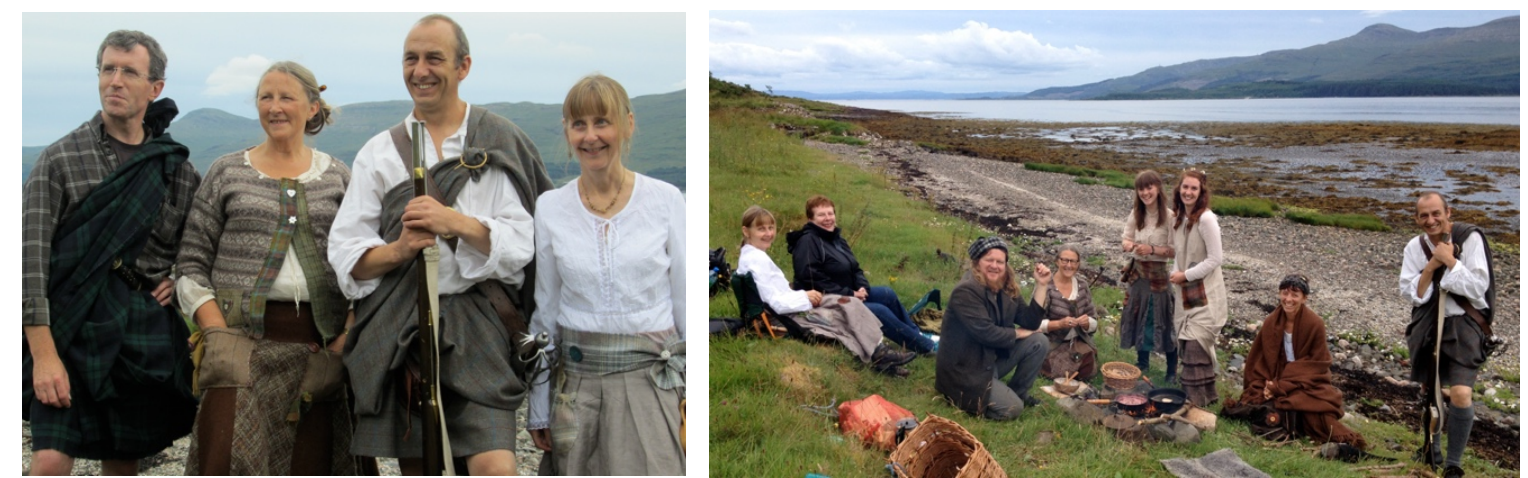

Figures $7 \& 8$. The facilitation team and their practices can be seen as an assemblage of humans with capacities to engage with the non-human elements of place in different ways which afforded interdisciplinary learning within the team. Members had backgrounds in storytelling, singing, basket weaving, geography, history, anthropology and drama and spanned a number of generations. The oldest, storyteller in the traveller tradition, was Essie Stewart. Several of the team were fluent Gaelic speakers. 
Reporting the research - as in this article and other outputs - involved creating assemblage communications that are themselves 'eventful'. This meant attending in accounting to ways of crating affective hybrids from the research assemblage to impact on research consumers. The use of video (on-line) and images here helps to exemplify this aspect as does the dissemination celebrations and exhibitions (see figures 9 and 10). Axiologically, these research practices are key to enacting new materialist eco-sociologies that seek "not only to analyse but to improve the world" (Fox and Alldred 2016, 52).
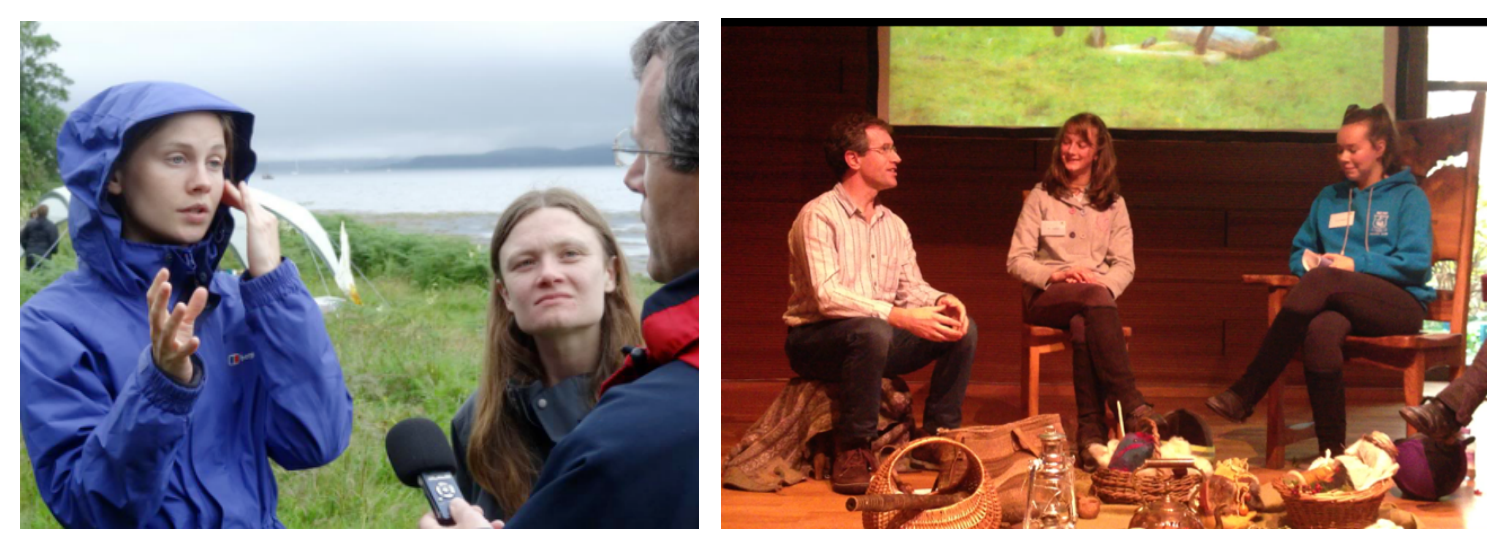

Figures $9 \&$ 10. In our assemblage-oriented research, interviewing happened mostly whilst events themselves were unfolding, fieldwork involved travelling with the team as they moved between schools and at community celebration days (figure 9). Figure 10 shows the Duke of Edinburgh Award group of young people on stage being interviewed in front of a live audience in the Storytelling Centre in Edinburgh, Scotland.

The stories young people created were often told to local audiences. Within an assemblage ontology, the agéncement of a research output too aims to produce an evocative account and calling for a response from readers.

In summary, we offer three orientations to Assemblage Pedagogy which were produced from the analysis of data in this project. 


\section{Assemblage Pedagogy}

\section{Orientation 1: Practice, facilitate, and entangle from the middle with the more-than-}

\section{human}

Honeyford and Watt (2017, drawing on Preston, 2015) see "assemblage pedagogies" as a form of 'burrowing' that is deeply connected to local settings, fundamentally productive, but also as dynamic and improvisational since they plug into and pull from other contexts in uncertain ways. Assemblage pedagogies demand reciprocal place-responsiveness from participating entities. As environmental and sustainability educators, assemblage pedagogies must take a purposeful way of planning and enacting with and through encounters with the more-than-human elements of place. The educational goal is to generate ESE learning as a result of significant coming together of people, places and practices. Assemblage pedagogies are designed and experienced through practicing, relating and becoming entangled with more-than-human elements and processes.

One project action involved four groups of teenagers using horses as a mode of travel which formed part of their Duke of Edinburgh Award. Each group travelled on horseback for several days on drove routes. Ahead of these trips, training was required, including navigation, camp-craft, natural horsemanship, and first aid. The role of the facilitator was key to understanding how educational experience was enabled through connecting people, place, other species, and practices in open-ended ways, as Bonnie (natural horsemanship teacher) explains: 
Bonnie: Being in an outside space and travelling from one place to another brings up thoughts and feeling that help younger people and children just explore where they are in themselves. [...] When we looked at the routes with the children we really did explore the past. [..] It started them asking lots of questions about it. [...] We talked about the post routes and the drovers and about hard life would have been for them.
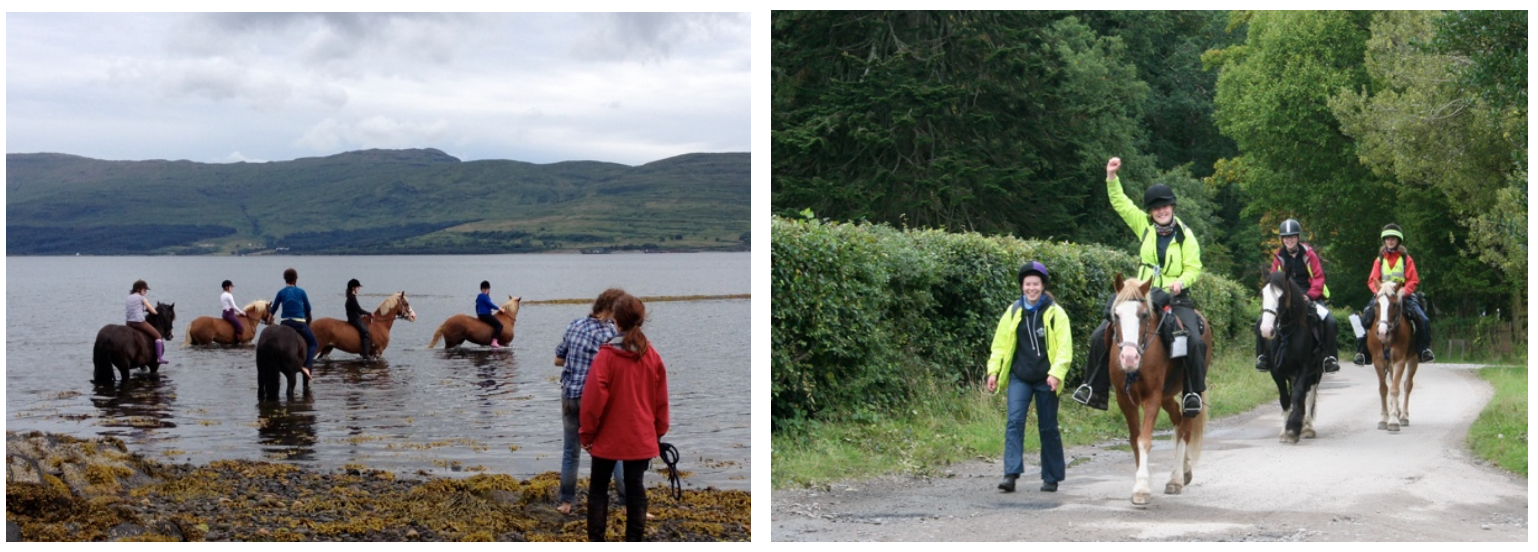

Figure 11 and 12. One DofE group on a practice ride arriving on the shores of Lochaline (Morvern, Scotland) and coming to the end of one of their journeys.

One of the young people noted the significance of horse-rider relations (see Renold and Ivinson 2014) in actualising learning to respond to more-than-human aspects such as terrain and their companion animal:

DofE Member: And we learnt what each different horse is like. [...] Gwen was probably the bravest one. So if there was something that the horses weren't sure about, like...like a bridge that didn't look very safe or something then we could always rely on Gwen to be the first one to cross so that the other horses would follow. So, it was good to know which horse we could rely on to do things like that. 
Sheila, facilitator in the programme, also noticed the reciprocal nature of response making with the more-than-human from which learning arose.

Sheila: They have worked so hard to get to this point. [...] I am not sure they actually really knew what they were taking on. So, it could have gone either way. [...] I think if they had given up, the ponies would have given up, 'cause the animals take their cues from them. If they had got stressed, the ponies would have got stressed. But they didn't.
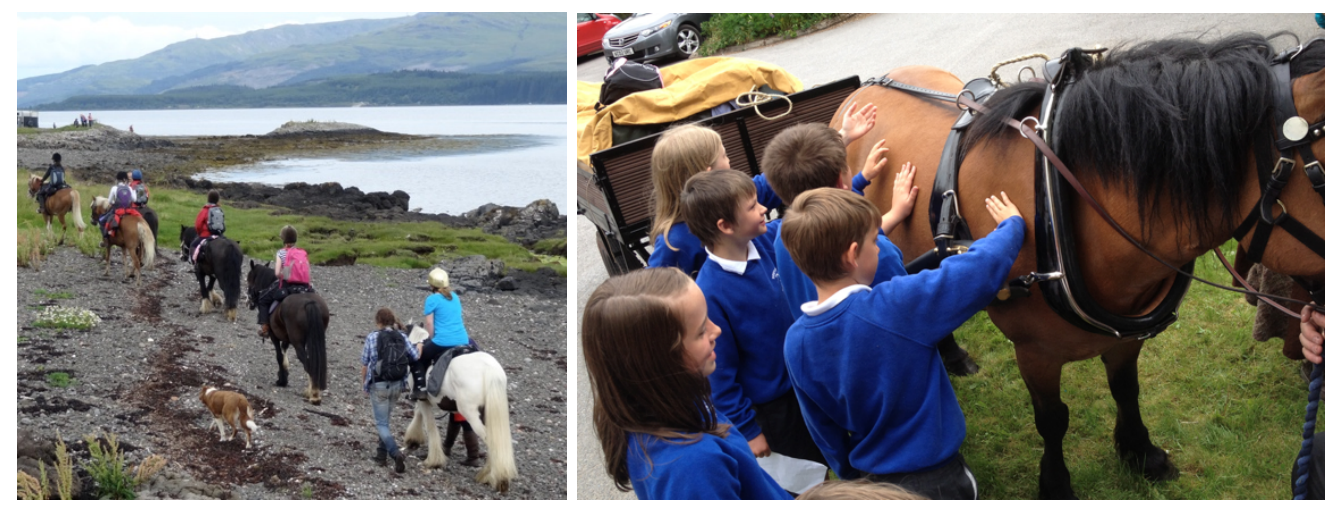

Figure 13 and 14. Across project activities, horses, as more-than-human agencies, played different roles in making journeying and the transportation of materials possible. The project participants also valued the opportunity to get to know particular horses by name and by character and which could be relied upon to lead over bridges or on uneven terrain.

ESE assemblage pedagogues need to actively seek out which key features in the biophysical and social environment are to be co-mingled and harnessed as features in a pedagogical way. They need to second guess which practices and interactions might afford or lead to learning about environmental issues, processes and problems, how to solve them, or at least lead to motivations to work towards solving them (after Stapp 1969). When well chosen, the encounters will be memorable, affective, significant and involve affective intensity. 
In assemblage ESE, practitioners will also likely need to consider the ethico-political nature of this task. On the one hand, we seek to catalyse, provoke becomings but these becoming cannot all be fully determined in advance in educational programme aims and objectives. Assemblage ESE desire for the emergence of new person-place relations that are more sustainable but heretofore are by definition and within an assemblage ontology as yet unexpressed. Within an assemblage approach to pedagogy, facilitators sustain relative yet important autonomy for the pedagogue as a socio-historically contextualised and connected agent. It is the ESE facilitator - alongside other participants (human and more-than-human) who plays a crucial role in orchestrating, sustaining and, later, dissolving pedagogical assemblages over time. In this project, educational facilitation came in many guises. Youth workers, horse trainers, artists and others helped catalyse opportunities for people of all ages to take part in local journeys of varying lengths from short walks of an hour or so, to expeditions lasting several days on horseback.

\section{Orientation 2: Interrupt existing assemblages and experiment within new ones}

Assemblage learning cannot be fully predetermined because it requires the on-going connections of agencies across the assemblage which are themselves in flux in unpredictable ways in pedagogical assemblages. Therefore, the assemblage pedagogue must interrupt, intervene and experiment. As Anderson et al. (2012) explain, new assemblages are needed to experiment with contemporary orderings. Understanding existing assemblages is a good

place to start but this is not sufficient for an assemblage approach to pedagogy. Being open to change is clearly a related requirement (Anderson et al. 2012). Another is having a desire to target what we see as ESE problems - these may be human-environment relational problems 
such as the biodiversity loss, climate change or where our food has come from in the past. Bazzul and Kayumova's (2016) analysis suggests that using environmental issues in assemblage pedagogies might create the kinds of ontological and epistemological openings for the wished-for changes we have yet to imagine.

Assemblage pedagogies commence by being purposefully unsure about what might become but uses problems to create openings that allow for new relations among people and place so that more sustainable ways of life might emerge. These new ways of life are, in Deleuze and Guattari's terms, the 'lines of flight' (see Bazzul and Kayumova 2016) that are needed to escape current norms and structures. The application of assemblage thinking to our contemporary context of unsustainability also usefully provides a way to link actual if emergent realities (material and discursive) with virtual possibilities into one frame. This is a challenge faced but not always addressed or theorised in his way in contemporary transformation and sustainability educational models.

A key feature of assemblage pedagogies is captured by the Deleuzian notions of deterritorialization and re-territorialization. Assemblage pedagogues actively seek to interrupt the contemporary flow of school life through the various project initiatives through repurposing what is available, to evoke and promote responses in learners. We were interested in assemblages that had the capacity affect and be affected by their constituent elements. To be educational, I suggest assemblage educators work will involve facilitating some coalescing of elements that result in desired emerging differences or 'lines of flight' (Deleuze and Guattari 1987, 338) for participants. Lines of flight can take elements of an existing assemblage and recompose them in new relationship to change an assemblage's expressions, norms and/or political realities. These lines of flight may be obstructed or reterritorialized 
(back into the pre-established assemblage) or become successful in more completely 'deterritorializing' existing assemblages and result in the creation of newly established assemblages (see Nail 2017). These ideas allow us to see how assemblage pedagogies have a socio-historical, political and transformative dimension but this is needs to be understood as a relational, human and non-human, expressive and embodied, discursive and material activity.
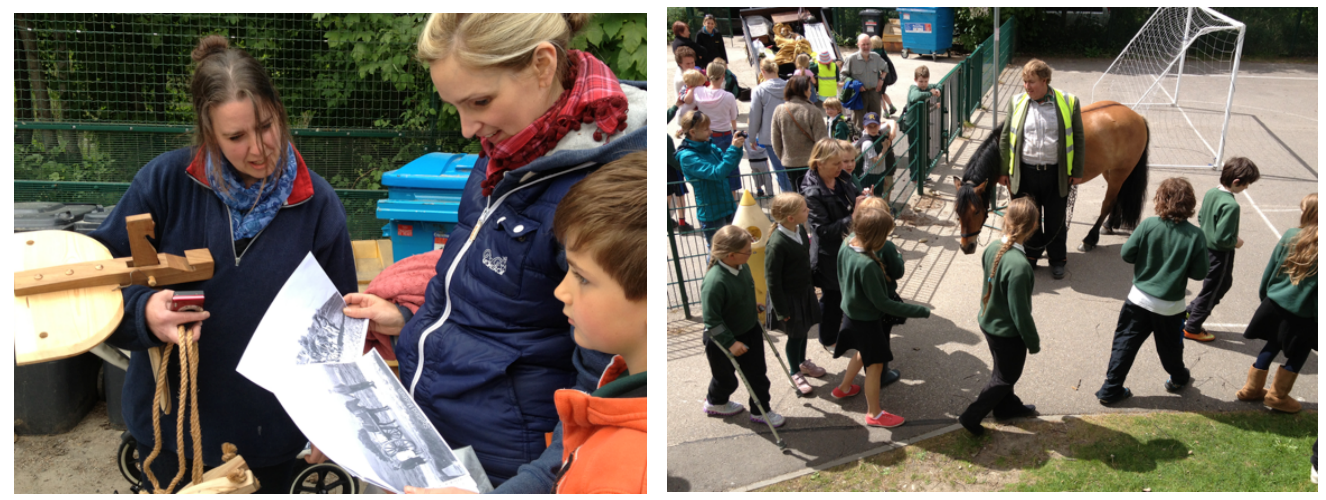

Figure 15 and 16. The role of the ponies in altering the relations between children, the outdoors, and the community was palpable throughout the project. In the 'Travelling Tales' project action, a pony and trap was used by the facilitation team to walk between primary schools over a three-day period. Stopping off at schools allowed for human-non-human encounters, time for parents to walk with pupils, and share knowledge about tack and saddles.

In our project, we actively sought to interrupt the contemporary flow of school life through the various project initiatives. As figure 15 and 16 (above) show, this involved appropriating spaces in new ways, working with other species (in this case horses, often Rosie, the dog, and at times, cattle, plants and other wildlife). The project at least temporarily de-territorialized school timetables, norms and routines to open up possibilities for learning across new boundaries: home-school, indoor-out, human and non-human, now and the past. Through camp craft and storytelling practices we sought to perform curriculum making differently evoking and promoting 'becoming-drover' sensibilities leading potentially to a reconsideration of life now, and, ultimately, in the future. 
After Deleuze, we can say we come to know at the same time as enacting a world through inhabiting it and becoming attuned in our senses, skills and dispositions to its "differences, positions and juxtapositions" (Anderson and Harrison 2010, 9). By this view, all 'representations' (such as written texts, maps, or artworks) are really better understood as presentations that coalesce to enact a world. Teaching and learning cannot be about content delivery alone or be solely based on mental constructivism. Assemblage educators will support and address learners' everyday performative embodiments in place collaborating in "experimenting with the corporeal sensibilities that are enfolded into how we learn to affect and be affected by the world, including relations with the non-human" (Anderson and Harrison 2010, 25). For Stories in the Land, we took a view that stories could be retold and recreated by children and adults in Gaelic and English for different community audiences as part of an outdoor landscape experience.
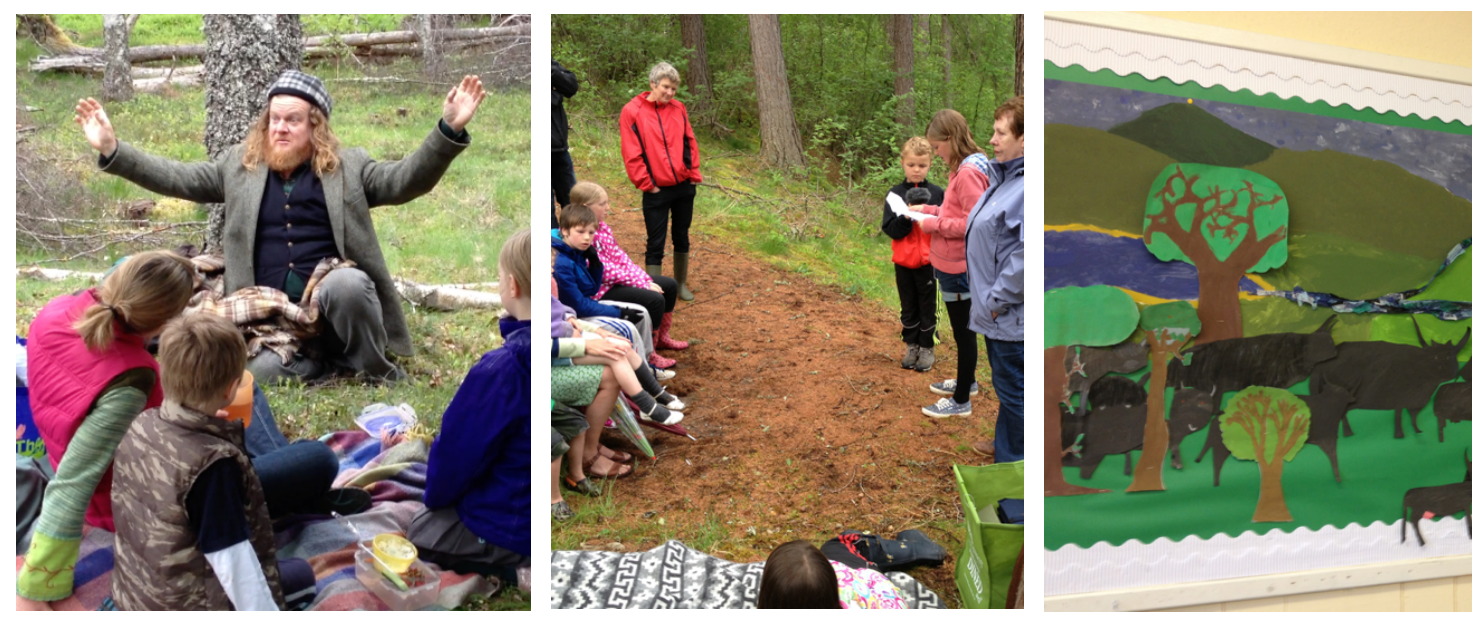

Figures 17, 18 and 19. Storytelling in action. Pupils also constructed and told their own stories.

Researcher: In what way do you think stories were in the land for you?

Primary Pupil: [They are] kinda tied into the land and everything. 
Other Pupil: Yeah, yeah.

Researcher: $\quad$ Stories are 'tied into the land'?

Primary Pupil: They're about places $[\ldots]$ and what they actually believed.

Primary Pupil: Stories help you learn about the past of your own place.

Primary Pupil: It's important to get more stories told in Scotland so they don't get forgotten.

Many eventful pedagogical assemblages arose and fell away across the life of the project.

These educational events are challenging to evidence in non-representational research. They happened through the ways in which humans and non-humans were involved in harnessing together and dispersing various entities such as animals (cattle, horses, wildlife), people (children, parents, community members), place elements (drove roads, weather), materials (saddles, food, tents and other heterogeneous elements of journeying). In addition to these, there was a harnessing of discursive elements (for example, the social history of droving, drovers' songs and stories, children's created stories, curricular framings, and policies around, for example, outdoor learning). Our intentional actions as educators can be, "compatible with the idea that the human being is both immersed in a world of nonhuman forces and inseparable from affective relations with nonhuman animals and other things" (Bowden 2015, 78). We become with the world (see also figures 20-22). 

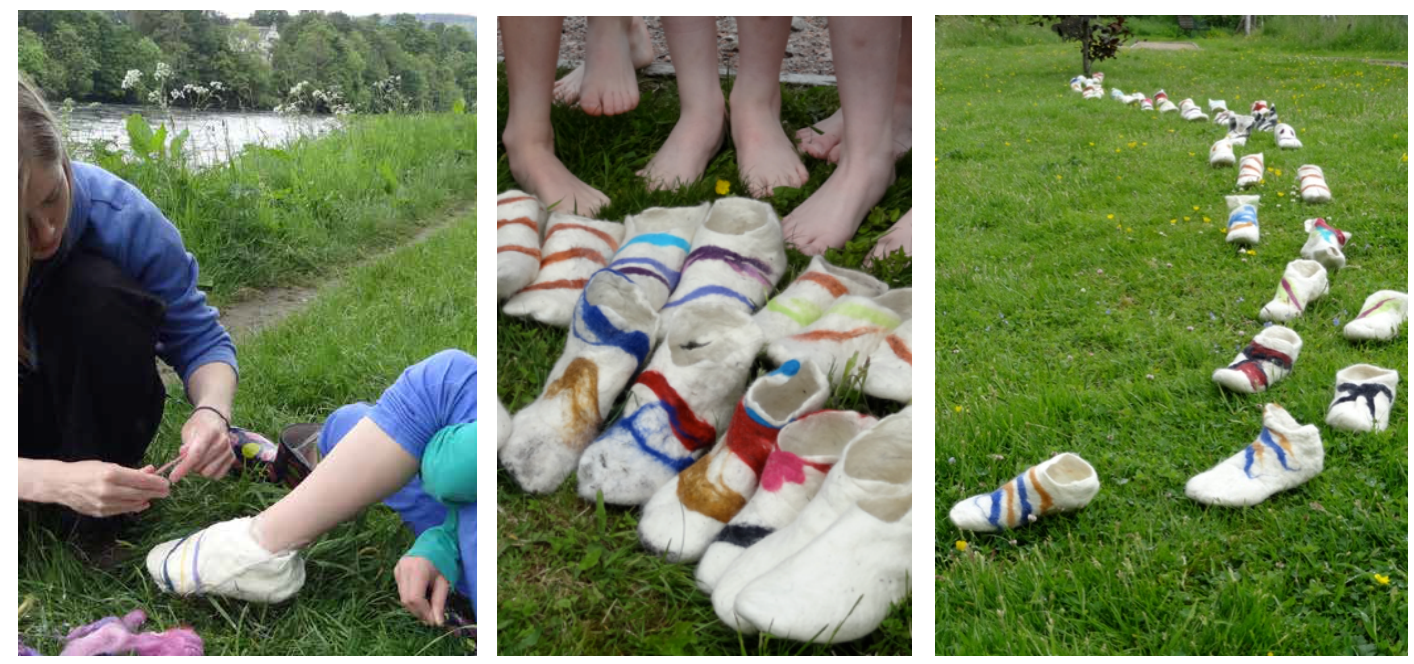

Figures 20, 21 and 22. Making and displaying the 'felt feet'. The 'felt feet' are created by agitating unspun woolen fibres with soapy water by placing the material on the feet within a bag inside one's footwear. Through walking, the fibres interlock and tangle into a new, firm, shaped piece of felt.

A core idea of Deleuze and Guattari (1994) is that it is always difference that gets repeated. This project action (see figures above) perhaps exemplifies this ontological idea in action. In this task, the participants were invited to place unspun sheep's wool inside their footwear. As the days journeying progressed, the effect of the children's walking was to create felt in the shape of their own feet inside their boots. In the process, wool becomes felt with the action of the person and the activity in a place. This experience shows how the heterogeneous material entanglements (of feet, different steps taken, local sheep, and footwear) produces each different boot with each different step imprinting a new difference. The tasks exemplify how difference gets repeated both in how each learner walked that day, and in how each felt boot emerges as a result. The boots display (figure 22) is an evocative visualization of the expression of the linked goals of learning about droving, learning via making, journeying and learning through becoming-with-materials. In assemblage pedagogies, we are called to teach, learn and research through acting in an immersed way within a cultural and material world, at 
one and the same time acting and undergoing changes in response to differences encountered. Teaching, learning, and researching are forms of becoming with the world.

\section{Summary}

ESE assemblage pedagogues can and must work in local and beyond-local ways to interrupt traditional education to experiment with bringing human and more-than-human entities into relation to create conditions of affective encounter for learners. We have shown that assemblage pedagogies can be about experimenting with/in place, producing affective expressions, reordering, de-territorializing and re-territorializing, tracing and interrupting the relations of heterogeneous elements into new purposeful assemblage for pedagogical ends.

Because not every collective, compilation or gathering is an assemblage, pedagogues and participants need to be 'assemblage convertors' (Bennett 2010, Buchanan 2015) who activate and co-ordinate specific types of gatherings and beings into consequential arrangements with purposes.

The elements in an assemblage are never contingent or purposeless. This is why I have suggested that 'arrangement' is better translation of agéncement than assemblage. It foregrounds more obviously the strong element of agency that underpins Deleuze and Guattari's original conception of the term. We cause our assemblages to be the way they are inasmuch that if they were arranged differently we would not be able to endure them. (Buchanan 2016, online) 
We have used our case analysis to derive the following more general orientations for Assemblage Pedagogy and Assemblage Research. We summarise them here as a framework for practitioners in ESE seeking to follow this approach in other settings.

To actualise Assemblage Pedagogy in ESE we might:

(1) Practice, facilitate, and entangle from the middle with the human and more-thanhuman to actualize the capacities for more sustainable ways of life,

(2) Interrupt existing assemblages and experiment with new ones to create more purposeful ESE pedagogies and research practices. Assemblages are pedagogical in that they can involve an intervention designed to describe, interrupt, and recast existing relations including existing educational relations. that involves a "resistance to closure and encourages a stress on open-endedness around the emergent and the already formed" (Anderson et al. 2012, 176), and,

(3) Evoke, story, and perform new expressions whilst becoming-with-the-world creating more sustainable ways of life. Educational assemblages have a purpose: to affect and be affected by the participants and to create new capacities.

For Assemblage Research, four practices reflect our approach here:

1. Analyse and collect from the middle. Researching what is 'becoming vital' in the midst, analyzing from the middle of flows and movements is a norm. Methods of collecting and analyzing are themselves a form of reciprocal response making in the midst of materials, practices, people and other entities within environments.

2. Evoke significance. Act to disclose local and wider significance via the data collection and analysis. This means attending to practices and performances of how desires, affect and influences impact in a given moment in time recognizing that this 
moment is part of a wider flow of desires and influence. Yet, we must not lose sight of how local and extra-local, contemporary and past practices relate and influence how what is assembled in the here and now.

3. Engage with the more-than-human. These may be entities, practices and processes: the capacity to influence or be influenced is not ascribed solely to people. A third orientation asks us to attend to the more-than-human entities, practices and processes, at times, perhaps, noticing what the role of other species in learning.

4. Attend reflexively to our own capacities. We reflexively draw upon our experience as researchers within research assemblages. We too are often implicated as participants within the very assemblages we research and the place-responsive research methodologies (Lynch and Mannion 2014) we might employ.

The (above) lists for pedagogy and for research overlap to some degree and they are not comprehensive and need to be further responded to and situated or place-plugged via one's own ethico-political judgements. Despite their partial nature and these limitations, they may be starting points to provoke further assemblage approaches in ESE.

\section{Discussion and Implications}

\section{Staying Open}

In this project, the purposeful pedagogical tasks required assemblages to bring key relevant entities into new affective relationships, often creating intense learning for participants in affecting and being affected by more-than-human others. Through coming to know practices 
experientially, learners can be prompted to create new forms of dwelling, journeying and storying. Assemblage pedagogies are based on a key idea that assemblages are undergoing on-going composition across human / more-than-human and other boundaries. In education, because of this radical relationality, our facilitation processes required an openness to outcomes that cannot all be predetermined. From ESE, the approach allows for a tentative open-ended exploration rather than a prescriptive approach to telling learners what living more sustainably might mean on a vulnerable and changing Earth. We need to "examine reality from within the intractabilities and ambiguities of the human perspective" [and] push towards an ecological politics: new ways of imagining living with the earth" (Saldahna and Stark 2016, 434-437).

\section{Encountering Differences}

In assemblage ESE, places are not backdrops to the social action, and generational relations are linked to place-person relations. This way of working means educators, learners, and their collaborators will actively seek out place-based intergenerational differences and work with these in more-than-representational expressions. Findings suggest that schools and other educational settings can benefit from enrolling local community members from diverse generations and harnessing places into emergent processes of curriculum making. By this view, learning is an all-age, emplaced process derived from encountering differences within social and material worlds. Because education is traditionally generationally-niched and indoor, intergenerational and outdoor educational practice are seen as particularly relevant (see Mannion 2017).

\section{Entangled Educator}


Not just any entanglement will form an assemblage with pedagogical reach. It is important here to notice that curriculum designers and pedagogues are not insignificant in the process of shaping educational throwntogetherness (Massey 2005). Creating an educational agéncement means purposefully selecting out some elements enrolling them into new relationships. Within ESE, the role of educators in activating and participating in assemblage pedagogies remains important. Bowden (2015) argues that entities, including pedagogues, when harnessed into any assemblage do maintain their autonomy. However, this autonomy must be understood as a form of on-going entangled association where we undergo experiences in the setting whilst acting too: "agency is inseparable from the different 'assemblages' of heterogeneous affective bodies that a given body enters into" (Bowden 2015, 61). Certainly, assemblage thinking means we must accept our contextualised embeddedness in settings, accepting that our bodies and practices are always entangled with the more-than-human, conditioning what happens, but not fully determining the on-going emergence. In outdoor ESE, this might include the roles of educators amid other agencies such as that of animal, amid other non-agential forces or effects coming from weather and terrain. An outdoor ESE facilitator will for sure be swayed in their decision making and participants will be affected by changing conditions in the environment. Our intentional will as educators - what we do and want to do - is always dependent on the forces and agencies of other entities. Different elements in an assemblage have different capacities to act, affect and be affected whilst participating. In fact, it is these differences that give rise to the educational and other effects of an assemblage. Assemblage theory allows us to consider the role of ESE pedagogues in intervening intentionally within educational processes of all kinds and not falling into a trap of human exceptionalism. Whether wearing the wool of a sheep on 
our feet or eating foraged food, participants were being and learning together (Snaza et al. 2014, 50) with non-humans.

\section{Becoming Sustainable}

To change educational practice, and to address the wicked problems of sustainability we desperately need new assemblages to interrupt the contemporary status quo. Agyeman et al. $(2003,2)$ defines sustainability as "the need to ensure a better quality of life for all, now and into the future, in a just and equitable manner, while living within the limits of supporting ecosystems". In this project, "quality of life for all' included humans and more-than-humans, whose relationality in local and wider trans-local environmental connections was raised as significant in place-responsive assemblage pedagogies. Walking and responding with/in place across the generational boundary had the potential to catalyse change in our ways of life and work as starting points for considering what it means to live a more sustainable life. Sustainability pedagogies need to be rooted in an awareness of the pasts of our current unsustainability. Understanding our own local histories in this interdisciplinary, intergenerational way seemed to be a viable if tentative exploration of what living more sustainably in the land might mean (Haluza Delay, DeMoor, and Peet 2013).

In sum, at a time when ESE should be striving for the ways to actualise how to live a sustainable life, assemblage thinking and pedagogy has a lot to offer. There is the orientation towards new embodied, emergent interconnections, understanding the formation of new planes of immanence between groups (learners and their communities, people and animals, communities and outdoor places), and the voicing of heretofore unvoiced (animals and other entities). New human and more-than-human educative assemblages can create new 
becomings (see Goodley 2007). Ontologically, assemblage ESE reminds us that what things, people and places are and what they are becoming are connected and open-ended. In Assemblage ESE, we can be less concerned with essences and more fully embrace a relational and processual approach. ESE then becomes an experiment based on evocative productive pedagogies of desire for change. Within assemblage pedagogies, the shifts required include from transmission to active inhabitation, experiencing with our bodies, witnessing and evoking through practice, from representation to creating more-thanrepresentative communicative expressions with new audiences, and from conforming to staying open to transforming, performing and responding to differences found in all kinds of places.

\section{Acknowledgements:}

Thanks especially to Dr. Joyce Gilbert, education officer at Royal Scottish Geographical Society who led the project. (See http://storiesintheland.blogspot.co.uk). Thanks also to participating schools and their communities, Coal Youth Centre, Storyline Scotland (Sally Harkness). Facilitators included: Alasdair Taylor, Essie Stewart, and Claire Hewitt (storytellers), Barney Strachan (sound artist), Alastair Davidson (bushcraft) Sarah Hughes and Richard Bracken (Room 13), Jane and Derry Wilkinson (willow), Alistair Strachan (historical re-enactment), Kate Langhorne (song and anthropology), Sheila Ryan (Duke of Edinburgh link), Bonnie Mealand (Ardgour Riding School), Ruaraidh Ormiston (Newtonmore Riding School). Thanks to the funders: Robertson Trust, Abernethy Trust, Ganochy Trust, Heritage Lottery, Ernest Cook Trust. For further information on the felt feet task, see https://bellacouche.com/feet-felt-walking-wool/

Biographical note. Dr Greg Mannion works as a senior lecturer in the Faculty of Social Sciences (Education) at University of Stirling, Scotland. His approach to educational research brings together theory and empirical perspectives on participation and rights-based education, intergenerational education, person-place relations, nature and culture. Much of his research looks at the way in which places can be important in the participation and learning for children and young people alongside adults and communities. In recent projects, his research considers local and global connectivity in education, place-responsive pedagogies, and the role of place and intergenerational dialogue in pupil participation in education. Web: https://www.stir.ac.uk/people/11039 


\section{References}

Agyeman, J., R.D. Bullard, and B. Evans, eds. 2003. Just Sustainabilities: Development in an unequal world. London: Earthscan.

Alaimo, S. and S. J. Hekman, eds. 2008. Material Feminisms. Bloomington, IN: Indiana University Press.

Anderson, B., and P. Harrison, 2010. "The promise of non-representational theory". In Taking-Place: Non-Representational Theory and Human Geography, edited by A. Anderson and P. Harrison, 1-34. London: Ashgate.

Anderson, B., M. Kearnes, C. McFarlane, and D. Swanton. 2012. "On assemblages and geography." Dialogues in Human Geography, 2: 171-189. doi: 10.1177/2043820612449261

Barad, K. 2003. "Posthumanist performativity: Toward an understanding of how matter comes to matter." Signs 28: 801-31. doi: 10.1086/345321

Barad, K. 2007. Meeting the Universe Halfway. Durham: Duke University Press.

Bazzul, J. and S. Kayumova. 2016. "Toward a Social Ontology for Science Education: Introducing Deleuze and Guattari's assemblages." Educational Philosophy and Theory, 48 (3): 284-299. doi: 10.1080/00131857.2015.1013016 
Bennett, J. 2010. Vibrant Matter: A Political Ecology of Things. Durham, NC: Duke University Press.

Bowden, S. 2015. "Human and non-human agency in Deleuze." In Deleuze and the Non/Human, edited by Rolfe, J. and H. Stark, 60-80. London: Palgrave Macmillan.

Braidotti, R. 2013. Posthuman humanities. European Educational Research Journal 12 (1): 1-19. doi: $10.1177 / 0263276407085156$

Buchanan, I. 2015. “Assemblage Theory and its Discontents”, Deleuze Studies 9 (3): 382 392. doi: $10.3366 /$ dls.2015.0193

Buchanan, I. 2016. “What Must We Do about Rubbish?” Drain Magazine, 13 (1). Available on-line: http://drainmag.com/what-must-we-do-about-rubbish/ accessed 17 April 2017.

Castree, N. 2004. Nature. London: Sage.

Clarke, D.A.G. and J. McPhie, 2016. "From places to paths: learning for sustainability, teacher education and a philosophy of becoming." Environmental Education Research, 22 (7): 1002-1024. doi: 10.1080/13504622.2015.1057554

Coole, D., and S. Frost, 2010. New Materialisms: Ontology, agency and politics. Durham, NC: Duke University Press.

Deleuze, G. 1994. Difference and Repetition, trans P. Patton. NY: Columbia. 
Deleuze, G. and C. Parnet. 1987. Dialogues. Columbia: Columbia University Press.

Deleuze, G. and F. Guattari. 1987. A Thousand Plateaus: Capitalism and Schizophrenia. Minneapolis: University of Minnesota Press.

Duhn, I. 2012a. "Places for pedagogies, pedagogies for places." Contemporary Issues in Early Childhood. 13 (2): 99-107. doi: 10.1177/1463949115585658

Duhn, I. 2012b “Making 'place' for ecological sustainability in early childhood education." Environmental Education Research, 18 (1): 19-29. doi: 10.1080/13504622.2011.572162

Duhn, I., Malone, K., and M. Tesar. 2017. "Troubling the intersections of urban/nature/childhood in environmental education.” Environmental Education Research, 23 (10): 1357-1368. doi: 10.1080/13504622.2017.1390884

Fawcett, L. 2002. “Children's wild animal stories: Questioning interspecies bonds.” Canadian Journal of Environmental Education, 7 (2): 125-139. doi: $10.1080 / 13504622.2017 .1325452$

Foucault, M. 1977. "Intellectuals and power - a conversation between Michel Foucault and Giles Deleuze". In Language, Counter-memory, Practice: selected essays and interviews by Michel Foucault, edited by D. Bouchard, 205-217. Oxford: Basil Blackwell. 
Fox, N. J. and P. Alldred. 2015. "New materialist social inquiry: designs, methods and the research-assemblage.” International Journal of Social Research Methodology, 18 (4): 399_ 414. doi: $10.1080 / 13645579.2014 .921458$

Fox, N., and P. Alldred. 2016. Sociology and the New Materialism. London: Sage.

Fox, N. J. and P. Alldred. 2017. "Mixed methods, materialism and the micropolitics of the research-assemblage.” International Journal of Social Research Methodology. Advance online publication. doi: 10.1080/13645579.2017.1350015

Gilbert, J. and G. Mannion. 2014. "Stories in the Land: in the tracks of the Highland drovers.” Scottish Local History. Spring, 88: 32-41. ISSN: 0266-2027.

Goodley, D. 2007. “Towards socially just pedagogies: Deleuzoguattarian critical disability studies.” International Journal of Inclusive Education, 11 (3): 317-334. doi:

$10.1080 / 13603110701238769$

Gough, N. 2016. "Postparadigmatic materialisms: A 'new movement of thought' for outdoor environmental education research?" Journal of Outdoor and Environmental Education, 19 (2): 51-65. ISSN: 2206-3301.

Green, M., and Duhn, I. 2015. “The force of gardening: investigating children's learning in a food garden." Australian Journal of Environmental Education 31 (1): 60-73. doi: $10.1017 /$ aee. 2014.45 
Hackett, A. and Somerville, M. 2017. "Posthuman literacies: Young children moving in time, place and more-than-human worlds.” Journal of Early Childhood Literacy 17 (3): 374-391. doi: $10.1177 / 1468798417704031$

Haldane, A.R.B. 2008. The Drove Roads of Scotland. Edinburgh: Birlinn Ltd.

Haluza-Delay, R., M.J. DeMoor, and C. Peet. 2013. “That We May Live Well Together in the Land...: Place Pluralism and Just Sustainability in Canadian and Environmental Studies.” Journal of Canadian Studies. 47 (3): 226-258.

Haraway, D.J. 2003. The Companion Species Manifesto: Dogs, people, and significant otherness. Chicago: Prickly Paradigm Press.

Haraway, D.J. 2008. When Species Meet. Minneapolis: University of Minnesota Press.

Honeyford, M.A. and J. Watt. 2017. "Burrowing and becoming: teaching writing in uncertain times." Pedagogies: An International Journal. Advance on-line publication. doi: 10.1080/1554480X.2017.1399797

Hultman, K. and H. Lenz Taguchi. 2010. "Challenging anthropocentric analysis of visual data: A relational materialist methodological approach to educational research." International Journal of Qualitative Studies in Education 23 (5): 525-542. doi:

$10.1080 / 09518398.2010 .500628$ 
Ingold, T. 1993. "The Art of Translation in a Continuous World." In Beyond Boundaries: Understanding, Translation and Anthropological Discourse, edited by G. Palsson, 210-230. Oxford: Berg.

Ingold, T. 2000. The perception of the environment: essays on livelihood, dwelling and skill. London: Routledge.

Ingold, T. 2003. “Two reflections on ecological knowledge.” In Nature knowledge: ethnoscience, cognition, identity edited by G. Sanga and G. Ortalli, 301-310. New York: Berghahn.

Ingold, T. 2012. "Toward an Ecology of Materials." Annual Review of Anthropology (41): 427-442. doi: 10.1146/annurev-anthro-081309-14592

Ingold, T. (2015) The Life of Lines. London: Routledge.

Jackson, A. Y. (2010). Deleuze and the girl. International Journal of Qualitative Studies in Education, 23 (5): 579-587. doi: 10.1080/09518398.2010.500630

Jackson, A. and L. Mazzei. 2012. Thinking with theory in qualitative research: Viewing data across multiple perspectives. New York: Routledge.

Lather, P. and E.A. St. Pierre. 2013. "Post-qualitative research.” International Journal of Qualitative Studies in Education 26 (6): 629-633. doi: 10.1080/09518398.2013.788752 
Latour, B. 2005 Reassembling the Social: An Introduction to Actor-Network-Theory. Oxford: Clarendon.

Leander, M. and D. Wells Rowe. 2006. "Mapping literacy spaces in motion: A rhizomatic analysis of a classroom literacy performance." Reading Research Quarterly 41 (4): 428-460. doi: 10.1598/RRQ.41.4.2

Lenz Taguchi, H. 2010. Going Beyond the Theory/Practice Divide in Early Childhood Education: Introducing an Intra-active Pedagogy. London: Routledge.

Lenz Taguchi, H. 2013. "Images of Thinking in Feminist Materialisms: Ontological divergences and the production of researcher subjectivities." International Journal of Qualitative Studies in Education 26(6): 706-716. doi: 10.1080/09518398.2013.788759

Lloro-Bidart, T. 2016. "A feminist posthumanist political ecology of education for theorizing human-animal relations/relationships.” Environmental Education Research 23 (1): 111-130. doi: $10.1080 / 13504622.2015 .1135419$

Lorimer, H. 2005. "Cultural geography: the busyness of being 'more-than-representational." Progress in Human Geography (29): 83-94. doi: 10.1191/0309132505ph531

Malone, K., S. Truong, and T. Gray. 2017. Reimagining sustainability in precarious times. Singapore: Springer. 
Mannion, G. 1999. Children's Participation in Changing School Grounds and Public Play

Parks in Scotland. Available online:

http://dspace.stir.ac.uk/bitstream/1893/88/1/Children\%27sParticipation\%20inChangingSchoo

1GroundsAndPlayParks.PDF Accessed $1^{\text {st }}$ Feb 2018.

Mannion, G. 2017. "Intergenerational Education: We are in a new place.” In Family,

Intergenerationality and Peer-Group Relations, edited by S. Punch and R. Vanderbeck.

London: Springer.

Mannion, G., A. Fenwick, and J. Lynch. 2013. "Place-responsive pedagogy: Learning from teachers' experiences of excursions in nature." Environmental Education Research 19 (6): 792-809. doi: 10.1080/13504622.2012.749980

Mannion, G. and J. Gilbert. 2015. “Place-responsive Intergenerational Education.” In Intergenerational Space, edited by R. Vanderbeck and N. Worth, 228-241. London: Routledge. ISBN: 978-0-415-85531

Masny, D. 2013. "Rhizoanalytic Pathways in Qualitative Research.” Qualitative Inquiry 19 (5): 339-348. doi: 10.1177/1077800413479559

Massey, D. 2005. For Space. Thousand Oaks, CA: Sage.

Mulcahy, D. 2012. “Affective assemblages: body matters in the pedagogic practices of contemporary school classrooms." Pedagogy, Culture and Society, 20 (1): 9-27. doi: $10.1080 / 14681366.2012 .649413$ 
Nail, T. 2017. "What is an Assemblage?" SubStance 46 (1): 21-37.

Pacini-Ketchabaw, V. and A. Taylor, eds. 2015. Unsettling the Colonialist Places and Spaces of Early Childhood Education. New York: Routledge.

Pickering, A. 2005. “Asian eels and global warming: A posthumanist perspective on society and the environment." Ethics and the Environment 10 (2): 29-43. doi:

10.1353/een.2005.0023

Rautio, P. 2013a. "Children who carry stones in their pockets: On autotelic material practices in everyday life." Children's Geographies 11 (4): 394-408. doi:

$10.1080 / 14733285.2013 .812278$

Rautio, P. 2013b. "Being nature: Interspecies articulation as a species-specific practice of relating to environment." Environmental Education Research 19 (4): 445-457. doi: $10.1080 / 14733285.2013 .812278$

Rautio, P. and J. Winston. 2013. "Things and children in play - improvisation with language and matter." Discourse: Studies in the Cultural Politics of Education 36 (1): 15-26. doi: $10.1080 / 01596306.2013 .830806$

Renold, E. and G. Ivinson. 2014. "Horse-girl assemblages: towards a post-human cartography of girls' desire in an ex-mining valleys community." Discourse: Studies in the Cultural Politics of Education 35 (3): 361-376. doi: 10.1080/01596306.2014.888841 
Ross, H. and G. Mannion. 2012. "Curriculum making as the enactment of dwelling in places." Studies in Philosophy and Education 313: 303-313. doi: 10.1007/s112

Saldanha, A. and H. Stark. 2016. "A New Earth: Deleuze and Guattari in the Anthropocene.” Deleuze Studies 10 (4): 427-439. doi: 10.3366/dls.2016.0237

Smith, T.A. and R. Dunkley. 2017. "Technology-non-human-child assemblages: reconceptualising rural childhood roaming." Children's Geographies. Advance on-line publication. doi: 10.1080/14733285.2017.1407406

Snaza, N., Appelbaum, P., Bayne, S., Carlson, D., Morris, M., Rotas, N., Sandlin, J., Wallin, J., \& Weaver, J. A. (2014). Toward a posthumanist education. Journal of Curriculum Theorizing, 30 (2): 39-55.

Snaza, N., and J. Weaver. 2015. Posthumanism and educational research. London: Routledge.

Somerville, M., K. Power, and P. de Carteret. 2009. Landscapes and Learning: Place Studies for a Global World. Rotterdam: Sense Publishing.

Springgay, S. and Truman, S.E (2017) On the need for methods beyond proceduralism: speculative middles, (in)tensions, and response-ability in research. Qualitative Inquiry 24 (3): 203-214. doi: $10.1177 / 1077800417704464$ 
St. Pierre, E.A. 2013. “The posts continue: becoming." International Journal of Qualitative Studies in Education 26 (6): 646-657. doi: 10.1080/09518398.2013.788754

St. Pierre, E.A. 2016. “The empirical and the new empiricisms.” Cultural Studies $\longleftrightarrow$ 一 Critical Methodologies 16 (2): 111-124. doi: 10.1177/1532708616636147

Stapp, W.B. 1969. “The concept of environmental education.” Environmental Education 1 (1): 30-31. doi: 10.1080/00958960903210031

Taylor, A. 2017. "Beyond stewardship: Common world pedagogies for the Anthropocene.” Environmental Education Research 23 (10): 1448-1461. doi: $10.1080 / 13504622.2017 .1325452$

Taylor, A. and M. Guigni. 2012. “Common Worlds: reconceptualising inclusion in early childhood communities." Contemporary Issues in Early Childhood 132: 108-119. doi: 10.2304/ciec.2012.13.2.108

Taylor, A., and V. Pacini-Ketchabaw. 2015. "Learning with children, ants, and worms in the Anthropocene: Towards a world pedagogy of multispecies vulnerability." Pedagogy, Culture and Society 23: 507-529. doi: 10.1080/14681366.2015.1039050

Thomas, G. 2011. "The case: generalisation, theory and phronesis in case study." Oxford Review of Education 37 (1): 21-35. doi: 10.1080/03054985.2010.521622 
Page 45 